\title{
FAKTOR-FAKTOR YANG MEMENGARUHI HARGA SAHAM PT LONDON SUMATRA INDONESIA TBK.
}

\author{
Ha Sudoni $^{1}$, Eti Suminartika ${ }^{2}$, Ernah $^{2}$ \\ 1) Mahasiswa Program Studi Ilmu Ekonomi Pertanian Pascasarjana Fakultas Pertanian Universitas \\ Padjadjaran \\ 2) Dosen Program Studi Ilmu Ekonomi Pertanian Pascasarjana Fakultas Pertanian Universitas \\ Padjadjaran \\ Jl. Raya Bandung-Sumedang KM.21, Jatinangor 40363;
}

\begin{abstract}
A b s t r ak
Perkebunan kelapa sawit dengan komoditas utama minyak sawit atau crude palm oil (CPO) merupakan sektor strategis dalam perekonomian Indonesia dengan memberikan kontribusi di tahun 2017 senilai USD 18,28 milyar, yang merupakan 9,6 \% terhadap ekspor nasional. Meski demikian sepanjang tahun 2010 sampai dengan tahun 2018 harga CPO dalam trend menurun. Penurunan harga CPO ini sejalan dengan penurunan harga saham perkebunan kelapa sawit di Bursa Efek Indonesia. PT London Sumatra Indonesia Tbk merupakan salah satu perusahaan perkebunan kelapa sawit yang harga sahamnya mengalami penurunan. Oleh karena itu investor yang akan berinvestasi di sektor perkebunan melalui bursa efek perlu melakukan penilaian dalam pengambilan keputusan investasi. Penelitian ini bertujuan mengidentifikasi faktor-faktor yang memengaruhi harga saham PT London Sumatra Indonesia Tbk. Hasil penelitian dengan menggunakan alat analisis regresi linier berganda didapat faktor-faktor yang memengaruhi harga saham PT London Sumatra Indonesia Tbk adalah harga CPO, harga saham market leader, kurs rupiah, Return On Equity dan Earning Per Share.
\end{abstract}

Kata kunci: minyak sawit, investor, harga saham

\begin{abstract}
Oil palm plantations with the main commodity palm oil or crude palm oil (CPO) are a strategic sector in the Indonesian economy by contributing in 2017 valued at USD 18.28 billion or $9.6 \%$ of national exports. However, throughout 2010 up to 2018 CPO prices were in a downward trend. The decline in CPO prices is in line with the decline in the prices of oil palm plantations on the Indonesia Stock Exchange. PT London Sumatra Indonesia Tbk is a palm oil plantation company whose share price has decreased. Therefore, investors who will invest in the plantation sector through the stock exchange need to make an assessment in making investment decisions. This study aims to identify the factors that influence the stock prices of PT London Sumatra Indonesia Tbk. The results of the study using multiple linear regression analysis tools obtained factors that influence the price of PT London Sumatra Indonesia Tbk stock prices are CPO prices, market leader stock prices, rupiah exchange rates, Return on Equity and Earning Per Share.
\end{abstract}

Keywords: crude palm oil, investor, stock prices 
Agricore Volume 4Nomor 2, Des 2019

Jurnal Agribisnis dan Sosial Ekonomi Pertanian UNPAD p-ISSN No. 2528-4576 / e-ISSN No. 2615-7411 


\section{Pendahuluan}

Pertanian merupakan sektor strategis dalam perekonomian Indonesia dimana industri kelapa sawit merupakan ekspor utama nasional. Nilai ekpor minyak sawit atau Crude Palm Oil (CPO) di tahun 2017 senilai USD 18,28 milyar, yang merupakan $55 \%$ dari total ekspor minyak sawit dunia sehingga menempatkan Indonesia sebagai pengekspor utama minyak sawit. Minyak sawit merupakan minyak nabati yang diekstraksi dari pulp buah kelapa sawit. Permintaan minyak sawit digunakan untuk bahan makanan, kosmetik dan bahan bakar nabati. Minyak sawit sebagai komoditas perkebunan dapat ditransaksikan di pasar komoditas internasional. Meski demikian sepanjang tahun 2010 sampai dengan tahun 2018 harga minyak sawit atau CPO dalam trend menurun. Penurunan harga $\mathrm{CPO}$ ini sejalan dengan penurunan harga saham perusahaan perkebunan kelapa sawit di Bursa Efek Indonesia. PT London Sumatra Indonesia Tbk merupakan salah satu perusahaan perkebunan kelapa sawit yang harga sahamnya dalam trend menurun. Dengan demikian investor perlu melakukan penilaian dalam pengambilan keputusan investasi di bursa efek agar tingkat pengembalian (return) investasi menguntungkan.

Saham PT London Sumatra Indonesia Tbk diperdagangkan di Bursa Efek Indonesia dengan pergerakan harga saham bersifat fluktuatif. Efficient Market Hypothesis merupakan konsep pasar yang efisien yang berarti harga saham yang sekarang mencerminkan segala informasi yang ada (Fama, 1970). Di dalam penelitian ini model penduga harga saham didasarkan pada faktor internal perusahaan berupa kinerja keuangan yang berkaitan dengan Return On Equity dan Earning Per Share. Model penduga harga saham juga didasarkan pada faktor eksternal yang merupakan faktor di luar kendali perusahaan namun diduga memiliki pengaruh terhadap perubahan harga saham yaitu harga CPO dan harga saham market leader serta nilai tukar atau kurs rupiah terhadap mata uang Amerika Serikat (US dollar).

Harga saham PT London Sumatra Indonesia Tbk yang diperdagangkan di BEI selama tahun 2010 sampai dengan tahun 2018 mengalami penurunan secara kuartalan hingga 36,22 \% dari Rp 1.960 menjadi Rp 1.250. Harga saham tertinggi dicapai pada periode kuartal Q2 tahun 2012 senilai Rp 2.875 dan harga saham terendah Rp 990 pada periode kuartal Q4 tahun 2015. Dengan demikian investor perlu mengumpulkan berbagai informasi baik dari segi internal maupun eksternal perusahaan yang diperlukan untuk pengambilan keputusan investasi. Keputusan investasi dalam perdagangan saham dapat berupa beli (buy), jual (sell) dan menahan saham (hold).

Informasi yang dipublikasikan sebagai suatu pengumuman akan memberikan sinyal bagi investor dalam pengambilan keputusan investasi. Jika pengumuman tersebut mengandung nilai positif, maka diharapkan pasar akan bereaksi pada waktu pengumuman tersebut diterima oleh pasar (Jogiyanto, 2000). Menurut Sharpe dkk (1997) pengumuman informasi akuntansi memberikan sinyal bahwa perusahaan mempunyai prospek yang baik di masa mendatang (good news) sehingga investor tertarik untuk melakukan perdagangan saham, dengan demikian pasar akan bereaksi yang tercermin melalui perubahan dalam volume perdagangan saham. Pada waktu informasi diumumkan dan semua pelaku pasar sudah menerima informasi tersebut, pelaku pasar terlebih dahulu menginterpretasikan dan menganalisis informasi tersebut sebagai sinyal baik (good news) atau sinyal buruk (bad news). Jika pengumuman informasi tersebut sebagai sinyal baik bagi investor maka terjadi kenaikan harga saham. Sedangkan jika pengumuman informasi tersebut sebagai sinyal buruk bagi investor maka terjadi penurunan harga saham. Sebagai contoh informasi peningkatan harga CPO, Return On Equity dan Earning Per Share akan mempunyai nilai positif dan diterima pasar sebagai sinyal baik (good news) bagi investor dalam pengambilan keputusan membeli saham. Hal ini membuat permintaan akan saham meningkat sehingga harga saham pun akan naik.

Selain dengan melihat pergerakan harga saham dalam pengambilan keputusan investasi, investor fokus terhadap kondisi keuangan perusahaan yang dapat dilihat dari analisis laporan keuangan. Dari analisis laporan keuangan dapat diketahui nilai Return On 
Equity dan Earning Per Share. Return On Equity adalah rasio penting bagi para pemilik dan pemegang saham karena rasio tersebut menunjukkan kemampuan perusahaan dalam mengelola modal dari pemegang saham untuk mendapatkan laba bersih (Lestari dkk, 2007). Kenaikan Return On Equity biasanya diikuti oleh kenaikan harga saham perusahaan tersebut (Chrisna, 2011). ROE menunjukan kemampuan perusahaan untuk menghasilkan laba setelah pajak dengan menggunakan modal sendiri yang dimiliki perusahaan. Investor yang akan membeli saham akan tertarik dengan ukuran profitabilitas ini, atau bagian dari total profitabilitas yang bisa dialokasikan ke pemegang saham (Hanafi dan Halim, 2012). Dengan demikian seandainya Return On Equity perusahaan meningkat, maka harga saham mengalami kenaikan karena semakin tinggi Return On Equity berarti semakin baik kinerja perusahaan dalam mengelola modalnya untuk menghasilkan keutungan bagi pemegang saham.

Di sisi lain harga saham dipengaruhi Earning Per Share. Earning Per Share atau disebut juga rasio nilai buku merupakan rasio untuk mengukur keberhasilan manajemen dalam mencapai keuntungan bagi pemegang saham. Rasio yang rendah berarti manajemen belum berhasil untuk memuaskan pemegang saham, sebaliknya dengan rasio yang tinggi, maka kesejahteraan pemegang saham meningkat dengan pengertian lain, bahwa tingkat pengembalian yang tinggi (Kasmir, 2010). Laba per saham (Earning Per Share) adalah laba bersih setelah pajak dibagi dengan jumlah lembar saham yang beredar (Syamsuddin, 2004). Tujuan perhitungan Earning Per Share adalah untuk melihat progres dari operasi perusahaan, menentukan harga saham dan menentukan besarnya dividen yang akan dibagikan (Machfoedz, 2000).

Investor juga memantau segi eksternal perusahaan yaitu harga $\mathrm{CPO}$ dan harga saham market leader dalam pengambilan keputusan investasi. Harga CPO secara kuartalan selama kuartal Q1 tahun 2010 sampai dengan kuartal Q4 tahun 2018 terkoreksi hingga 35,69\% dari USD 832 per metrik ton menjadi USD 535,02. Penurunan harga CPO berdampak negatif pada industri kelapa sawit karena memengaruhi penerimaan perusahaan yang merupakan sinyal buruk (bad news) bagi investor sehingga menjual atau melepas saham (sell) dan harga saham pun menurun. Di sisi lain selain harga CPO yang menjadi perhatian investor dalam pengambilan keputusan investasi dari segi eksternal perusahaan adalah harga saham market leader PT Astra Agro Lestari Tbk. Secara kuartalan selama kuartal Q1 tahun 2010 sampai dengan kuartal Q4 tahun 2018 harga saham market leader PT Astra Agro Lestari Tbk menurun hingga 51,93\% dari Rp 24.600 menjadi Rp 11.825 yang membuat investor PT London Sumatra Indonesia Tbk menjual atau melepas saham (sell) sehingga harga saham pun menurun karena penurunan harga saham market leader menyebabkan saham perkebunan kelapa sawit lainnya termasuk PT London Sumatra Indonesia Tbk mengalami penurunan.

Selain harga CPO dan harga saham market leader, investor juga memantau kondisi makro ekonomi dalam pengambilan keputusan investasi. Menurut Tandelilin (2010) variabel makro ekonomi yang perlu diperhatikan investor antara lain adalah tingkat suku bunga, tingkat inflasi, kurs rupiah, produk domestik bruto (PDB), anggaran defisit, investasi swasta, serta neraca perdagangan dan pembayaran. Menurut Bodie dkk (2007) faktor makro ekonomi yang dapat memengaruhi harga saham, antara lain suku bunga, inflasi dan nilai tukar. Sehingga jika kondisi nilai tukar rupiah diperkirakan buruk, maka kemungkinan besar refleksi pada indeks harga saham yang akan menurun. Hal ini karena pelemahan kurs rupiah terhadap mata uang asing merupakan sinyal negatif bagi investor sehingga akan memengaruhi harga saham tersebut (Ang, 1997).

Berdasarkan hasil penelitian terdahulu pengujian model untuk menjelaskan harga saham menggunakan variabel independen yang beragam. Raharjo dan Muid (2013) menggunakan variabel independen Return On Equity (ROE), Return On Assets (ROA), Debt To Equity Ratio (DER), Current Ratio (CR), Earning Per Share (EPS) dan Book Value Per Share (BVS) untuk menjelaskan model harga saham. Hasil penelitian menunjukan ROE, ROA, DER, CR, EPS, dan BVS secara simultan memiliki pengaruh yang signifikan terhadap harga saham. Yumia dan Khairunnisa (2015) menggunakan variabel independen Return On 
Equity (ROE), Earning Per Share (EPS), dan Price Earning Ratio (PER) untuk menjelaskan model harga saham. Hasil penelitian menunjukan ROE, EPS dan PER secara simultan mempunyai pengaruh signifikan terhadap harga saham. Pengujian model secara parsial Return On Equity dengan harga saham menunjukkan hasil yang signifikan. Temuan ini didapat pada hasil penelitian Raharjo dan Muid (2013), Yumia dan Khairunnisa (2015) dan Kamar (2017) yaitu ROE berpengaruh signifikan terhadap harga saham. Sedangkan pengujian secara parsial Earning Per Share dengan harga saham menunjukkan hasil yang signifikan. Temuan ini didapat pada hasil penelitian Christian dan Frecky (2019), Fadila dan Saifi (2018) dan Kumar (2017) yaitu EPS secara parsial berpengaruh signifikan terhadap harga saham. Pengujian secara parsial kurs rupiah dengan harga saham menunjukkan hasil yang signifikan. Temuan ini didapat pada hasil penelitian Mardiyati dan Rosalina (2013) dan Meta (2005) yaitu kurs rupiah secara parsial berpengaruh signifikan terhadap harga saham. Pengujian secara parsial harga CPO dengan harga saham menunjukkan hasil yang signifikan. Temuan ini didapat pada hasil penelitian Kewinoto dkk (2015) yaitu harga CPO secara parsial berpengaruh signifikan terhadap harga saham.

Dengan demikian harga saham PT London Sumatra Indonesia Tbk dipengaruhi oleh kondisi internal keuangan perusahaan yang indikatornya di antaranya Return On Equity dan Earning Per Share. Jika Return On Equity dan Earning Per Share mengalami kenaikan, harga saham PT London Sumatra Indonesia Tbk juga mengalami kenaikan dan sebaliknya jika Return On Equity dan Earning Per Share mengalami penurunan harga saham PT London Sumatra Indonesia Tbk mengalami penurunan pula. Selain itu harga saham PT London Sumatra Indonesia Tbk dipengaruhi oleh kondisi eksternal perusahaan yaitu harga CPO, harga saham market leader dan kurs rupiah. Jika harga saham harga CPO dan harga saham market leader mengalami kenaikan, harga saham PT London Sumatra Indonesia Tbk juga mengalami kenaikan dan sebaliknya jika harga CPO dan harga saham market leader mengalami penurunan harga saham PT London Sumatra Indonesia Tbk mengalami penurunan pula. Harga saham juga dipengaruhi oleh kondisi makro ekonomi yaitu kurs rupiah terhadap US dollar. Jika kurs rupiah mengalami kenaikan harga nilai tukarnya terhadap US dollar atau disebut melemah (terdepresiasi), harga saham akan mengalami penurunan dan berlaku sebaliknya, jika kurs rupiah terhadap US dollar menguat maka harga saham mengalami kenaikan. Oleh karena itu penelitian ini menganalisis pengaruh harga $\mathrm{CPO}$, harga saham market leader, kurs rupiah, Return On Equity dan Earning Per Share terhadap harga saham PT London Sumatra Indonesia Tbk.

\section{Metodologi Penelitian}

Jenis penelitian ini adalah studi kasus (case study). Penelitian studi kasus merupakan strategi penelitian dimana di dalamnya peneliti menyelidiki secara cermat suatu program, peristiwa, aktivitas, proses, atau sekelompok individu (Creswell, 2014). Studi kasus dalam penelitian ini adalah harga saham PT London Sumatra Indonesia Tbk yang diperdagangkan di Bursa Efek Indonesia. Adapun metode penelitian dilakukan dengan pendekatan kuantitatif. Metode penelitian kuantitatif merupakan pendekatan guna menguji teori obyektif dengan memeriksa hubungan antar variabel. Variabel-variabel ini, pada gilirannya, dapat diukur, biasanya pada instrumen, sehingga data bernomor dapat dianalisis menggunakan prosedur statistik (Creswell, 2014).

Emiten yang digunakan dalam penelitian ini menggunakan pertimbangan subjektif dan diharapkan dapat mencerminkan kondisi korporasi perusahaan perkebunan kelapa sawit yang ada di Indonesia di tengah-tengah penurunan harga CPO. Menurut Bungin (2014) pertimbangan subjektif adalah pertimbangan berkisar tentang kredibilitas peneliti terhadap apa yang akan ditelitinya.

Adapun pemilihan subjek penelitian PT London Sumatra Indonesia Tbk dengan menggunakan kriteria :

a. PT London Sumatra Indonesia Tbk merupakan emiten perkebunan penghasil kelapa sawit yang masih beroperasi sejak pada tahun 1906 dan terdaftar di Bursa Efek Indonesia sejak pencatatan saham perdana (initial public offering) pada tanggal 7 Juni 1996.

b. Emiten tersebut memiliki data laporan 
keuangan kuartalan serta dipublikasikan dari kuartal Q1 tahun 2010 hingga kuartal Q4 tahun 2018, dengan jumlah laporan keuangan sebanyak 36 data secara runtun (time series).

c. Saham emiten tersebut diperdagangkan saat jam kerja di Bursa Efek Indonesia.

Teknik pengumpulan data dalam penelitian ini menggunakan data sekunder. Data sekunder diperoleh melalui studi pustaka dari data yang ada di perusahaan. Studi pustaka adalah teknik pengumpulan data dengan mengadakan studi penelaah terhadap buku-buku, literatur-literatur, catatan-catatan, dan laporan-laporan yang ada hubungannya dengan masalah yang dipecahkan (Nazir, 2013). Data dikumpulkan dan diuji kredibilitasnya dengan metode pendugaan model yang digunakan adalah regresi linier berganda. Dalam model penelitian ini variabel operasional penelitian adalah harga CPO, harga saham market leader, kurs rupiah, Return On Equity dan Earning Per Share yang diduga merupakan faktor-faktor yang memengaruhi harga saham PT London Sumatra Indonesia Tbk.

Tabel 1. Variabel Operasional Penelitian

\begin{tabular}{|c|c|c|c|c|}
\hline No & Variabel & Perhitungan & Satuan & Skala \\
\hline 1. & $\begin{array}{l}\text { Harga saham } \\
\text { PT London } \\
\text { Sumatra } \\
\text { Indonesia Tbk }\end{array}$ & $\begin{array}{l}\text { Harga saham } \\
\text { penutupan } \\
\text { (closing price) }\end{array}$ & Rupiah & Rasio \\
\hline 2. & Harga CPO & $\begin{array}{l}\text { Harga CPO di } \\
\text { pasar komoditas } \\
\text { CIF Rotterdam }\end{array}$ & $\begin{array}{l}\text { USD per } \\
\text { metrik } \\
\text { ton }\end{array}$ & Rasio \\
\hline 3. & $\begin{array}{l}\text { Harga Saham } \\
\text { market leader } \\
\text { PT Astra Agro } \\
\text { Lestari Tbk }\end{array}$ & $\begin{array}{l}\text { Harga saham } \\
\text { penutupan } \\
\text { (closing price) }\end{array}$ & Rupiah & Rasio \\
\hline 4. & $\begin{array}{l}\text { Nilai tukar } \\
\text { rupiah (Kurs) }\end{array}$ & $\begin{array}{l}\text { Harga mata } \\
\text { uang rupiah } \\
\text { terhadap mata } \\
\text { uang US dollar }\end{array}$ & Rupiah & Rasio \\
\hline 5. & $\begin{array}{l}\text { Return On } \\
\text { Equity (ROE) }\end{array}$ & $\begin{array}{l}\text { ROE = Laba } \\
\text { bersih setelah } \\
\text { pajak/Ekuitas }\end{array}$ & Persen & Rasio \\
\hline 6. & $\begin{array}{l}\text { Earning Per } \\
\text { Share (EPS) }\end{array}$ & $\begin{array}{l}\text { EPS = Laba } \\
\text { bersih setelah } \\
\text { pajak/Jumlah } \\
\text { saham }\end{array}$ & Rupiah & Rasio \\
\hline
\end{tabular}

Di dalam model penduga ada beberapa syarat uji yang harus dipenuhi agar menjadi valid sebagai alat peramalan yaitu dengan dilakukan Uji Statistik melalui pengujian koefisien determinasi (R square), Uji F dan Uji t. Dari hasil analisis tersebut dapat diketahui koefisien regresi model peramalan dan arah hubungan sebab akibat antara variabel independen dengan variabel dependen.

\section{Hasil dan Pembahasan}

Sebelum perhitungan estimasi model maka dilakukan Uji Statistik melalui uji koefisien determinasi, Uji $F$ dan Uji t. Hasil analisis model harga saham PT London Sumatra Indonesia Tbk adalah sebagai berikut :

$\operatorname{HLSIP}(\mathrm{Y})=1.213,313+1,277 \mathrm{HCPO}+0,037$ HAA - 0,093 Kurs -138,907 ROE + 13,183 EPS $+e$

dimana :

HLSIP = Harga saham PT London Sumatra Indonesia

$$
\begin{array}{ll}
\text { HCPO }=\text { Harga CPO } \\
\text { HAA }=\text { Harga saham market leader PT Astra } \\
\text { Agro } & \text { Lestari Tbk } \\
\text { Kurs } & =\text { Harga mata uang rupiah terhadap US } \\
\text { dollar } & \\
\text { ROE } & =\text { Return On Equity } \\
\text { EPS } & =\text { Earning Per Share } \\
e & =\text { error }
\end{array}
$$

Tabel 2. Hasil Perhitungan Estimasi Model Harga Saham

\begin{tabular}{lrrl}
\hline Variabel & $\begin{array}{c}\text { Koefisien } \\
\text { Regresi }\end{array}$ & t hitung & t Sig. \\
\hline Konstanta & $1.213,313$ & & \\
HCPO & 1,277 & 2,667 & $0,012^{* *}$ \\
HAA & 0,037 & 3,684 & $0,001^{* * *}$ \\
Kurs & $-0,093$ & $-2,421$ & $0,022^{* *}$ \\
ROE & $-138,907$ & $-2,299$ & $0,029 * *$ \\
EPS & 13,183 & 1,807 & $0,081^{*}$ \\
R square & 0,827 & & \\
F hitung & 28,625 & & \\
F tabel Sig. $\alpha=1 \%$ & 3,70 & & \\
t tabel Sig. $\alpha=1 \%$ & & & \\
(2-tailed) & 2,75000 & & \\
t tabel Sig. $\alpha=5 \%$ & & \\
(2-tailed) & & \\
t tabel Sig. $\alpha=10 \%$ \\
(2-tailed)
\end{tabular}


** = Nyata pada tingkat kepercayaan $95 \%$

* = Nyata pada tingkat kepercayaan $90 \%$

\section{Hasil Analisis Uji Statistik}

Hasil pengujian koefisien determinasi diperoleh nilai $\mathrm{R}$ square $\left(\mathrm{R}^{2}\right)$ sebesar 0,827 (Tabel 2), yang berarti bahwa $82,7 \%$ variabel independen dapat menerangkan model yang terdiri dari variabel harga CPO, harga saham market leader, kurs rupiah, Return On Equity, Earning Per Share, sedangkan sisanya sebesar $17,3 \%$ dijelaskan oleh variabel-variabel lain yang tidak terdapat dalam model.

Hasil Uji $\mathrm{F}$ didapat nilai $\mathrm{F}$ hitung $>\mathrm{F}$ table, dimana $\mathrm{F}$ hitung $=28,625>\mathrm{F}$ tabel $=3,70$ (Tabel 2). Dengan demikian secara bersamasama atau simultan variabel harga CPO, harga saham market leader, kurs rupiah, Return On Equity, Earning Per Share berpengaruh signifikan terhadap harga saham PT London Sumatra Indonesia Tbk.

Hasil Uji t secara parsial didapat harga CPO berpengaruh positif dan signifikan terhadap harga saham PT London Sumatra Indonesia Tbk pada selang kepercayaan $95 \%$. Harga saham market leader berpengaruh positif dan signifikan pada selang kepercayaan $99 \%$. Earning Per Share berpengaruh positif dan signifikan pada selang kepercayaan $90 \%$. Kurs rupiah berpengaruh negatif dan signifikan pada selang kepercayaan $95 \%$. Return On Equity berpengaruh negatif dan signifikan terhadap harga saham PT London Sumatra Indonesia Tbk pada selang kepercayaan $95 \%$ (Tabel 2).

\section{HASIL DAN PEMBAHASAN}

Harga CPO memiliki nilai koefisien regresi sebesar 1,277 pada selang kepercayaan $95 \%$, yang berarti kenaikan harga $\mathrm{CPO}$ sebesar 1 USD per metrik ton dapat meningkatkan harga saham PT London Sumatra Indonesia Tbk sebesar 1,277 rupiah dalam kondisi cateris paribus. Hasil penelitian ini sejalan dengan penelitian sebelumnya yang dilakukan Kewinoto dkk (2015) yaitu harga CPO berpengaruh positif dan signifikan terhadap harga saham perusahan perkebunan kelapa sawit. Perusahaan menjual CPO berdasarkan harga CPO internasional sehingga semakin tinggi harga $\mathrm{CPO}$ penerimaan perusahaan semakin besar. Hal ini merupakan sinyal baik bagi investor yang membuat permintaan saham meningkat sehingga harganya pun akan naik.
Harga saham market leader PT Astra Agro Lestari Tbk memiliki nilai koefisien regresi sebesar 0,037 pada selang kepercayaan $99 \%$, yang berarti kenaikan harga saham market leader PT Astra Agro Lestari Tbk sebesar 1 rupiah dapat meningkatkan harga saham PT London Sumatra Indonesia Tbk sebesar 0,037 rupiah dalam kondisi cateris paribus. Ketika pasar saham mulai mengalami kebangkitan, saham market leader yang pertama kali menguat dengan signifikan (May, 2019). Saham PT Astra Agro Lestari Tbk merupakan saham market leader yang memimpin penguatan harga saham perusahaan kelapa sawit. Ketika saham perusahaan kelapa sawit mulai mengalami kenaikan, saham PT Astra Agro Lestari Tbk yang pertama kali menguat disusul PT London Sumatra Indonesia Tbk.

Kurs rupiah terhadap US dollar memiliki nilai koefisien regresi sebesar $-0,093$ pada selang kepercayaan $95 \%$, yang berarti kenaikan kurs rupiah sebesar 1 rupiah dapat menurunkan harga saham PT London Sumatra Indonesia Tbk sebesar 0,093 rupiah dalam kondisi cateris paribus. Hasil penelitian ini sejalan dengan penelitian sebelumnya yang dilakukan Pujawati dkk (2015), Mardiyati dan Rosalina (2013) dan Meta (2005) yaitu kurs rupiah berpengaruh negatif dan signifikan terhadap harga saham. Saat nilai rupiah terdepresiasi artinya keadaan perekonomian Indonesia sedang mengalami gejolak. Gejolak perekonomian dalam negeri akan menurunkan minat investor dalam berinvestasi karena keadaan perekonomian yang kurang baik akan mendorong naiknya prosentase risiko dalam berinvestasi (Gumilang dkk, 2014). Apabila nilai US dollar cenderung menguat, maka pada saat yang sama perekonomian nasional juga ikut tertekan dan akan berdampak pula terhadap pergerakan Indek Harga Saham Gabungan (IHSG) yang juga cenderung menurun. Investor akan cenderung mengalihkan dananya dalam bentuk investasi lainnya, jika nilai rupiah terdepresiasi terhadap US dollar (Sudirman, 2018). Saat rupiah terdepresiasi investor akan beralih investasi dengan return investasi tetap seperti Obligasi Ritel (ORI) karena ORI memiliki risiko yang lebih sedikit sebab negara membackup investasi ini (DBS Bank, 2019).

Return On Equity memiliki nilai koefisien regresi sebesar $-138,907$ pada selang 
kepercayaan $95 \%$, yang berarti kenaikan Return On Equity sebesar 1 persen dapat menurunkan harga saham PT London Sumatra Indonesia Tbk sebesar 138,907 rupiah dalam kondisi cateris paribus. Hasil penelitian ini tidak sejalan dengan penelitian sebelumnya yang dilakukan oleh Kamar (2017), Tumandung dkk (2017), Yumia dan Khairunnisa (2015), Sharif dkk (2015), Manoppo (2015), Ngmenipuo (2015), Astutik dkk (2014) dan Hutami (2012) yaitu Return On Equity mempunyai pengaruh positif dan signifikan terhadap harga saham. Hal ini berarti investor tidak melihat ROE sebagai keputusan dalam membeli saham, melainkan bertindak spekulasi (Rahmadewi dan Abundanti, 2018). Samuelson dan Nordhaus (1997) mengungkapkan kegiatan spekulatif dalam pasar modal muncul karena adanya harapan terpenuhi dengan sendirinya, maksudnya jika seseorang membeli saham tertentu dengan harapan nilai saham akan naik, maka tindakan ini akan mendorong kenaikan harga-harga saham yang bersangkutan. Keadaan ini membuat orang semakin terdorong untuk membeli saham lagi dan hal ini menyebabkan kenaikan harga saham lagi. Di sisi lain penelitian ini menunjukan hasil sebaliknya yaitu ROE berpengaruh negatif dan signifikan terhadap harga saham. Hasil penelitian ini sejalan dengan penelitian Rahmadewi dan Abundanti (2018) Setyorini dkk (2016), Sukmawati dan Garsela (2016) dan Husaini, (2012) yaitu Return On Equity mempunyai pengaruh negatif dan signifikan terhadap harga saham.

Earning Per Share memiliki nilai koefisien regresi sebesar 13,183 pada selang kepercayaan $90 \%$, yang berarti kenaikan Earning Per Share sebesar 1 rupiah dapat meningkatkan harga saham PT London Sumatra Indonesia Tbk sebesar 13,183 rupiah dalam kondisi cateris paribus. Hasil penelitian ini sejalan dengan penelitian sebelumnya yang dilakukan Christian dan Frecky (2019), Fadila dan Saifi (2018), Kumar (2017), Satryo dkk (2016), Inyiama dan Ozouli (2015), Sharif dkk (2015), Manoppo (2015) dan Wang dkk (2013) yaitu Earning Per Share berpengaruh positif dan signifikan terhadap harga saham. Bagi para investor, informasi EPS merupakan informasi yang dianggap paling mendasar dan berguna, karena bisa menggambarkan prospek earning perusahaan di masa mendatang. Apabila EPS yang dihasilkan sesuai dengan harapan investor, maka keinginan investor untuk menanamkan modalnya juga meningkatkan harga saham seiring dengan tingginya permintaan saham (Tandelilin, 2001). Semakin tinggi nilai EPS semakin besar laba yang disediakan untuk pemegang saham (Darmadji dan Fakhruddin, 2001). Dengan demikian informasi peningkatan Earning Per Share akan diterima pasar sebagai sinyal baik bagi investor yang membuat permintaan saham meningkat sehingga harganya pun akan naik.

\section{KESIMPULAN DAN SARAN \\ Kesimpulan}

Faktor-faktor yang memengaruhi harga saham PT London Sumatra Indonesia Tbk adalah harga CPO, harga saham market leader, kurs rupiah, Return On Equity dan Earning Per Share. Harga CPO, harga saham market leader dan Earning Per Share berpengaruh positif dan signifikan terhadap harga saham PT London Sumatra Indonesia Tbk yaitu kenaikan harga CPO, harga saham market leader dan Earning Per Share akan meningkatkan harga saham PT London Sumatra Indonesia Tbk. Sedangkan Return On Equity dan kurs rupiah berpengaruh negatif dan signifikan terhadap harga saham PT London Sumatra Indonesia Tbk yaitu kenaikan kurs rupiah dan Return On Equity akan menurunkan harga saham PT London Sumatra Indonesia Tbk.

\section{Saran}

Perusahaan perlu meningkatkan kinerja keuangan melalui kenaikan laba bersih sehingga indikator Earning Per Share meningkat, dengan demikian harga saham perusahaan mengalami kenaikan sebagai cermin kepercayaan investor dalam berinvestasi di PT London Sumatra Indonesia Tbk.

\section{Daftar Pustaka}

Astutik, Eva Dwi, Surachman dan Atim Djazuli. (2014). The Effect of Fundamental and Technical Variables On Stock Price (Study On Manufacturing Companies Listed in Indonesia Stock Exchange). Journal of Economics, Business, and Accountancy Ventura Vol. 17 No. 3 Tahun $2014,345-352$. 
Bodie, Z., A. Kane, A. J. Marcus. (2007). Investment (7th Ed). New York: McGrowHill.

Bungin, Burhan. 2014. Metodologi Penelitian Kualitatif. Kencana Prenamedia Group, Jakarta.

Chrisna, Heriyati. 2011. Pengaruh Return On Equity, Net Interest Margin dan Dividend Payout Terhadap Harga Saham Perbankan di Bursa Efek Indonesia. Tesis. Magister Akuntansi Sekolah Pascasarjana Universitas Sumatera Utara.

Christian, Natalis dan Frecky. (2019). Analisis Pengaruh Faktor-Faktor yang Mempengaruhi Harga Saham pada Perusahaan yang Terdaftar di Bursa Efek Indonesia. Jurnal Benefita 4 (1) Februari 2019, 115-136.

Creswell, J. W. (2014). Research Design: Qualitative, Quantitative and Mixed Methods Approaches, 4 Edition. London: Sage.

Darmadji, Tjiptono dan Hendy M.Fakhruddin. (2001). Pasar Modal di Indonesia. Salemba Empat, Jakarta.

DBS Bank. (2019). Investasi Menguntungkan Saat Rupiah Melemah. Diambil 7 September 2019 , https://www.dbs.id/id/smeid/businessclass/articles/money/investasimenguntungkan-saat-rupiah-melemah

Fama, E. (1970). Efficient Capital Markets: A Review of Theory and Empirical Work. The Journal of Finance, 25, 383-417.

Fadila, Rahmawati dan Muhammad Saifi. (2018). Pengaruh Earning Per Share (EPS), Return On Equity (ROE) dan Net Profit Margin (NPM) Terhadap Harga Penutupan Saham (Studi pada Perusahaan Perbankan yang Terdaftar di Bursa Efek Indonesia Tahun 2014-2016). Jurnal Administrasi Bisnis (JAB) Vol. 61 No. 3 Agustus 2018.

Gumilang, Reshinta Candra, R. Rustam Hidayat dan Maria Goretti Wi Endang NP. (2014). Pengaruh Variabel Makro Ekonomi, Harga Emas dan Harga Minyak Dunia Terhadap Indeks Harga Saham Gabungan (Studi pada Bursa Efek Indonesia Periode 2009-2013). Jurnal Administrasi Bisnis (JAB) Vol. 14 No. 1 September 2014.
Hanafi, Mahduh dan Abdul Halim, (2012). Analisis Laporan Keuangan. UPP STIM YKPN, Yogyakarta.

Husaini, Achmad. (2012). Variabel Return On Assets, Return On Equity, Net Profit Margin dan Earning Per Share Terhadap Harga Saham Perusahaan. Jurnal Profit Vol. 6 No. 1 Juni 2012, 46-49.

Hutami, Rescyana Putri. (2012). Pengaruh Dividend Per Share, Return On Equity Dan Net Profit Margin Terhadap Harga Saham Perusahaan Industri Manufaktur Yang Tercatat di Bursa Efek Indonesia Periode 2006-2010. Jurnal Nominal Vol. I No. 1 Tahun 2012, 104-123.

Inyiama, Oliver Ike dan Caroline Ozouli (2015). Does Eaning Per Share Determine Market Price of Ordinary Share? Evidence From Nigeria Banking Sector (2000 2013). European Journal of Accounting Auditing and Finance Research Vol. 3 No. 7 July 2015, 21-32.

Jogiyanto. (2000). Teori Portofolio dan Analisi Investasi. BPEE UGM, Yogyakarta.

Kamar, Karnawi. (2017). Analysis of the Effect of Return on Equity (ROE) and Debt to Equity Ratio (DER) on Stock Price on Cement Industry Listed in Indonesia Stock Exchange (Idx) in the Year of 2011-2015. IOSR Journal of Business and Management (IOSR-JBM), Vol. 19 Issue 5 Tahun 2017, 66-76.

Kasmir. (2010). Analisis Laporan Keuangan. PT Raja Grafindo Persada, Jakarta.

Kewinoto, Johnnywinata, Muchtar Mariso dan Sjahruddin. (2015). Analisis Pengaruh Harga Komoditas Minyak Kelapa Sawit (CPO), Tingkat Inflasi, Nilai Tukar Rupiah dan Volume Penjualan Komoditas (CPO) Terhadap Harga Saham Pada Perusahaan Penghasil Kelapa Sawit (CPO) Yang Terdaftar di Bursa Efek Indonesia Pada Tahun 2008-2012. JOM FEKON Vol. 2 No. 1 Februari 2015, 1-18.

Kumar, P. (2017). Impact of Earning Per Share and Price Earning Ratio On Market of Share: A Study On Auto Sector in India. International Journal of Research Granthaalayah Vol. 5 February 2017, 113 118.

Lestari, Annio Indah N, Muslich Lutfi dan Syahyunan (2007). Pengaruh Faktor Fundamental dan Teknikal Terhadap 
Harga Saham Properti yang Terdaftar di Bursa Efek Jakarta. Jurnal Ekonomi, Bisnis dan Akuntansi Vol. 2 No. 2, 87109.

Machfoedz, Mas'ud. (2000). Akuntansi Manajemen, Buku I. BPFE Yogyakarta, Yogyakarta.

Manoppo, Carmela Pinky. (2015). The Influence of ROA, ROE, ROS and EPS on Stock Price. Jurnal EMBA 691 Vol.3 No. 4 Tahun 2015, 691-697.

Mardiyati, Umi dan Ayi Rosalina. (2013). Analisis Pengaruh Nilai Tukar, Tingkat Suku Bunga dan Inflasi Terhadap Indeks Harga Saham, Studi Kasus Pada Perusahaan Properti yang Terdaftar di Bursa Efek Indonesia. Jurnal Riset Manajemen Sains Indonesia (JRMSI) Vol. 4 No. 1 Tahun 2013.

May, Ellen. (2019). Bagaimana Cara Menemukan Leading Stocks?. Diambil 7 September 2019, http://ellenmay.com/market-updates/educationalarticles/bagaimana-cara-menemukanleading-stocks

Meta, Rayun Sekar. (2005). Perbedaaan Pengaruh Inflasi, Tingkat Suku Bunga dan Nilai Tukar Rupiah/US Dollar Terhadap Return Saham. Jurnal Ekonomi STUE Surakarta, Oktober 2005.

Nazir, Moh. (2013). Metode Penelitian. Ghalia Indonesia, Bogor.

Ngmenipuo, Iddrisu Mohammed. (2015). The Impact of Comprehensive Income Reporting on Financial Performance of Ghanaian Firms With Public Accountability. International Journal of Economics, Commerce and Management United Kingdom Vol. III Issue 3 Maret 2015.

Samuelson, Paul A dan William P Nordhous. 1997. Makro Ekonomi, Edisi Keempatbelas. Erlangga, Jakarta.

Pujawati, Putu Eka dkk. (2015). Pengaruh Nilai Tukar Rupiah terhadap Return Saham dengan Profitabilitas (ROE) sebagai Variabel Intervening. E-Jurnal Ekonomi dan Bisnis Universitas Udayana 4.04 Tahun 2015, 220-242.

Rahmadewi, Pande Widya dan Nyoman Abundanti. (2018). Pengaruh EPS, PER, $C R$ dan ROE Terhadap Harga Saham di Bursa Efek Indonesia. E-Jurnal
Manajemen Unud Vol. 7 No. 4 Tahun 2018.

Satryo, A. G., N. A. Rokhmania dan P. Diptyana. (2016). The Influence of Profitability Ratio, Market Ratio and Solvency Ratio on The Share Prices of Companies Listed On LQ 45 Index. The Indonesian Accounting Review Vol. 6 No. 1 January - July 2016, 55 - 66.

Setyorini, Maria M. Minarsih dan Andi Tri Haryono. (2016). Pengaruh Return On Assets (ROA), Return On Equity (ROE) dan Earning Per Share (EPS) Terhadap Harga Saham Perusahaan Real Estate di Bursa Efek Indonesia (Studi Kasus pada 20 Perusahaan Periode 2011-2015). Journal of Management Volume 2 No. 2 Maret 2016.

Sharif, T., H. Purohit dan R. Pillai. (2015). Analysis of Factors Affecting Share Prices: The Case of Bahrain Stock Exchange. International Journal of Economics and Finance Vol. 7 No. 3 Tahun 2015.

Sharpe, William dkk. (1997). Investment. Prenhallindo, Jakarta.

Sudirman. 2018. Pengaruh Perubahan Nilai Tukar Rupiah Tengah US Dollar Terhadap Indeks Harga Saham Gabungan (IHSG) di Bursa Efek Indonesia. Jurnal Al-Buhuts Vol. 1 No. 1 Juni 2018, 1-17.

Sukmawati, Fitri dan Innes Garsela. (2016). The Effect of Return On Assets and Return On Equity To The Stock Price. Advances In Economics, Business And Management Research Vol. 15 Tahun 2016, 53-57.

Syamsudin, Lukman. (2004). Manajemen Keuangan Perusahaan, Edisi ke 8. PT Raja Grafindo, Jakarta.

Tandelilin, Eduardus. (2001). Analisis Investasi dan Manajemen Portofolio, Edisi Pertama. BPFE Yogyakarta, Yogyakarta.

Tandelilin, Eduardus. (2010). Portofolio dan Investasi, Teori dan Aplikasi Edisi Pertama. Kanisius, Yogyakarta.

Tumandung, Cristin Oktavia, Sri Murni dan Dedy N Baramuli. (2015). Analisis Pengaruh Kinerja Keuangan Terhadap Harga Saham Pada Perusahaan Makanan dan Minuman Yang Terdaftar di BEI Periode 2011 - 2015. Jurnal EMBA Vol. 5 No. 2 Juni 2017. 
Wang, Junjie, Gang Fu dan Chao Luo. (2013). Accounting Information and Stock Price Reaction of Listed Companies, Empirical Evidence from 60 Listed Companies in Shanghai Stock Exchange. Journal of Business \& Management Vol. 2, Issue 2 Tahun 2013, 11-21.

Yumia, Martisa Nabila dan Khairunnisa. (2015). Pengaruh Return On Equity (ROE), Earning Per Share (EPS) dan Price Earning Rasio (PER) Terhadap Harga Saham. e-Proceeding of Management Vol. 2 No. 3 Tahun 2015. 